\title{
ASSÉDIO MORAL NO AMBIENTE DE TRABALHO E A RESPONSABILIDADE CIVIL DO EMPREGADOR
}

\section{MORAL HARASSMENT IN THE WORKPLACE AND THE EMPLOYER'S CIVIL RESPONSIBILITY}

\section{Raquel Costa Silva Simões}

Acadêmica do $10^{\circ}$ período do curso de direito da Faculdade Presidente Antônio Carlos de

Teófilo Otoni.

E-mail raquelcscontato@gmail.com

\section{Paula Corrêa Rodrigues}

Professora do Curso de Direito da Faculdade Presidente Antônio Carlos de Teófilo Otoni. E-mail direitoadjunto@unipacto.com.br

Recebido: 01/05/2020 - Aceito: 20/05/2020

\section{Resumo}

O presente artigo científico versa sobre o assédio moral no ambiente de trabalho e as consequências para o assediador tomando-se como parâmetro as disposições doutrinárias, legislativas e jurisprudenciais. $\mathrm{O}$ assédio moral atinge o psicológico do trabalhador afetando, por conseguinte, seu bem-estar no ambiente de trabalho. Percebe-se através do presente estudo que tem se tornado rotina o trabalhador ser submetido a situações humilhantes e maus tratos nas relações de trabalho. No entanto, medidas judiciais podem ser tomadas para minimizar os danos sofridos pelo agressor. Assim, o objetivo da pesquisa é analisar os elementos caracterizadores do assédio moral e a possibilidade de indenização pela ofensa praticada no ambiente de trabalho. As abordagens feitas no presente artigo foram realizadas através de pesquisas bibliográficas exploratórias, análises de jurisprudências, artigos, legislações e doutrinas. Pode-se observar que o assédio moral no ambiente de trabalho ocorre muitas vezes em decorrência da competitividade ou pela busca de um profissional que seja ideal para o mercado de trabalho, fazendo-se necessário desenvolver medidas de prevenção no ambiente laboral a fim de conscientizar os funcionários das consequências judiciais e psicológicas de uma conduta ofensiva.

Palavras-chaves: Assédio moral. responsabilidade civil. legislação trabalhista.

\section{Abstract}

This scientific article deals with bullying in the workplace and the consequences for the 
harasser, taking doctrinal, legislative and jurisprudential provisions as a parameter. Moral harassment affects the worker's psychological, thus affecting their well-being in the workplace. It can be seen through this study that it has become routine for workers to be subjected to humiliating situations and mistreatment in work relationships. However, judicial measures can be taken to minimize the damage suffered by the aggressor. Thus, the objective of the research is to analyze the elements that characterize bullying and the possibility of compensation for the offense practiced in the workplace. The approaches made in this article were carried out through exploratory bibliographic research, analysis of jurisprudence, articles, legislation and doctrines. It can be observed that moral harassment in the workplace often occurs due to competitiveness or the search for a professional who is ideal for the job market, making it necessary to develop preventive measures in the workplace in order to raise awareness officials of the judicial and psychological consequences of an offensive conduct.

Keywords: Bullying. civil responsability. labor legislation.

\section{INTRODUÇÃO}

O ambiente de trabalho é o local onde a maioria das pessoas passam a maior parte do seu dia. Com o passar do tempo as relações de trabalho vão se enfatizando e como consequência natural as pessoas vão se agrupando com os colegas que se relacionam melhor e mantendo uma certa distância daqueles que não conseguem identificar afinidades ou que já tiveram algum ruído na comunicação ou no relacionamento.

É a partir das situações cotidianas do ambiente de trabalho que pode vir a surgir determinadas condutas que acabam por ferir, humilhar e desestabilizar um colega de trabalho ou funcionário. A essas atitudes ofensivas, vexatórias, humilhantes que ocorrem no ambiente labora é que se denomina de assédio moral.

O assédio moral é toda e qualquer conduta utilizada por alguma pessoa ou grupo, através de seus comportamentos, gestos e atos escritos, atingindo diretamente a pessoa assediada, causando danos psicológicos, físicos e violando sua dignidade humana.

No ambiente de trabalho, o assédio moral ocorre por meio de ações abusivas advindas do assediador, que usa de meios repetitivos, de perseguição com intenção de ofender a vítima causando nela o sentimento de inferioridade, atitude essa que prolonga por muito tempo.

O objetivo deste artigo é analisar o assédio moral no trabalho, a responsabilidade civil e as consequências e implicações jurídicas para quem pratica o assédio moral no trabalho.

Pode-se perceber que o assédio moral acarreta transtornos e danos físicos e psicológicos para a vítima assediada, e que segundo os estudos levantados é possível 
classificá-lo em: assédio moral vertical, horizontal e misto.

O assédio moral é um problema que tem provocado interesse de boa parte da sociedade, em razão das repercussões causadas pela sua ocorrência.

A responsabilidade civil também é abordada no presente artigo, onde buscou-se analisar o que é e quais são os elementos caracterizadores para que exista a obrigação de indenizar os danos causados.

Além disso, destaca-se que no ano de 2017 com o advento da reforma trabalhista houve mudanças sobre a forma de reparação do dano moral no trabalho, entre elas a incidência da indenização de acordo com o salário da vítima assediada.

Para a construção deste artigo foi feita uma pesquisa bibliográfica exploratória, sendo que algumas doutrinadoras foram essenciais para o desenvolvimento das ideias expostas, são elas: Marie France Hirigoyem (2010) e Maria Aparecida Alkimim (2008).

Para o desenvolvimento da temática, abordar-se-á sobre o assédio moral no trabalho e as modalidades existentes como: assédio moral horizontal, vertical descendente e ascendente, e por fim o misto. Na sequência, destacar-se-á a responsabilidade civil e o assédio moral no trabalho; e por fim, não menos importante tratar-se-á sobre a Dignidade da Pessoa Humana e a legislação trabalhista.

\section{BREVE HISTÓRICO DO ASSÉDIO MORAL}

Antes de analisar o que é o assédio moral no trabalho é fundamental a compreensão de seu surgimento nas relações de trabalho em uma breve análise histórica.

No início da humanidade as pessoas viviam em situações de igualdade, onde não havia diferenças de níveis econômicos, sendo o trabalho utilizado apenas para sobrevivência (DARCANCHY, 2006) ${ }^{1}$.

Sobre o surgimento do assédio moral, Marques Júnior (2014) explica que o assédio moral teve origem na época da escravidão, onde os escravos eram tratados com humilhações psicológicas e físicas, tornando-se propriedade do seu senhor.

Guedes (2008, p. 25) afirma que:

No começo de 1984, o cientista sueco Heinz Leymann publica, num pequeno ensaio científico, o resultado de uma longa pesquisa pelo National Board of Occupational Safety and Health in Stokolm, no qual demonstra as consequências do mobbing, sobretudo na esfera neuropsíquica, da pessoa exposta a um comportamento humilhante no trabalho durante um certo tempo, seja por parte de superiores, seja

\footnotetext{
${ }^{1}$ https://jus.com.br/artigos/7765
} 
dos colegas de trabalho.

No Brasil, o assédio moral existe desde a escravidão, com tratamento humilhantes e forte terror psicológico, época essa marcada por perseguições, desigualdades, famílias separadas, castigos severos resultando até em morte. Mesmo depois do fim da escravidão nos anos de 1980, ainda existia pessoas trabalhando de forma escrava, como nos casos dos imigrantes que sofriam de assédio moral e sexual. (MELO, 2017) ${ }^{2}$

Em 2002, no Brasil, foi proferida a primeira decisão sobre assédio moral, um marco histórico, o acordão 7660/2002 de autoria da Juíza do TRF $17^{\circ}$ Região, Dra. Sônia das Dores Dionísio que decidiu pela condenação por assédio moral nos autos do recurso ordinário $\mathrm{n}^{\circ}$ TRT- $17^{\circ}$ RO-1315.2000.00.17.00-1 que aduz:

\begin{abstract}
ASSÉDIO MORAL - CONTRATO DE INAÇÃO - INDENIZAÇÃO POR DANO MORAL - A tortura psicológica, destinada a golpear a autoestima do empregado, visando forçar sua demissão ou apressar a sua dispensa através de métodos que resultem em sobrecarregar o empregado de tarefas inúteis, sonegar-lhe informações e fingir que não o vê, resultam em assédio moral, cujo efeito é o direito à indenização por dano moral, porque ultrapassa o âmbito profissional, eis que minam a saúde física e mental da vítima e corrói a sua autoestima. No caso dos autos, o assédio foi além, porque a empresa transformou o contrato de atividade em contrato de inação, quebrando o caráter sinalagmático do contrato de trabalho, e por consequência, descumprindo a sua principal obrigação que é a de fornecer o trabalho, fonte de dignidade o empregado. (TRT $-17^{\mathrm{a}} \mathrm{R}-\mathrm{RO} \mathrm{n}^{\circ}$ 1315.2000.00.17.00-1 - Rela . Sônia das Dores Dionísa) (CAVALCANTE, 2005)³
\end{abstract}

A partir dessa decisão o assédio moral no Brasil, foi ganhando reconhecimento sendo que várias outras decisões surgiram ao longo da história, garantindo direitos às vítimas à reparação do dano causado e definindo de forma mais clara o que é o assédio moral no trabalho e quais os meios utilizados pelo agressor.

\title{
2.1 Conceito
}

No entendimento de Hirigoyen (2010) o assédio moral no ambiente de trabalho é tudo que se configura como uma forma de violência, onde a vítima fica exposta por um longo período a práticas humilhantes e constrangedoras advindas de uma ou mais pessoas no trabalho. A principal finalidade desse comportamento é de humilhar, ofender, diminuir ou causar desestabilização emocional no trabalhador, atingindo direta ou indiretamente sua saúde psicológica e física, além de prejudicar o ambiente de trabalho.

\footnotetext{
${ }^{2}$ https://jus.com.br/artigos/57476/a-evolucao-historica-do-assedio-moral-nas-relacoes-de-trabalho-no-brasil-eno-mundo

${ }^{3}$ https://jus.com.br/artigos/6457
} 
A psicóloga francesa Hirigoyen (2010, p. 17) conceitua o Assédio Moral como sendo:

O assédio moral no trabalho é definido como qualquer conduta abusiva (gesto, palavra, comportamento, atitude [...]) que atente, por sua repetição ou sistematização, contra a dignidade ou integridade psíquica ou física de uma pessoa, ameaçando seu emprego ou degradando o clima de trabalho.

Neste contexto, pode-se perceber que a pessoa assediadora pode usar de diversos meios para alcançar seu objetivo, usando do poder e do seu cargo, desestabilizando profissionalmente e emocionalmente o trabalhador, levando-o a muitas vezes a pedir demissão.

As ações podem advir de comportamentos inofensivos, que, no entanto, geram constrangimentos na vítima causando nela sentimento de inferioridade, atingindo sua dignidade pessoal e traumas irreversíveis.

Aguiar (2006) defende que o assédio moral advém de conflitos entre chefes e subordinados, e em algumas situações pode ocorrer entre os próprios colegas de serviço, além disso tem-se o assédio moral praticado pelo subordinado contra o seu chefe.

\subsection{Espécies de Assédio Moral no trabalho}

De acordo com Alkimin (2008, p. 61) o assédio moral é dividido em três modalidades, sendo elas: assédio horizontal, assédio misto e o assédio vertical que por sua vez se subdivide em vertical descendente e ascendente. A forma com mais incidência é a vertical descendente, aquele que é praticado entre o empregador ou qualquer outro superior hierárquico, como supervisores, gerentes, diretores e outros que possuírem poder de comando.

\subsubsection{Assédio horizontal}

O assédio horizontal é conceituado por Alkimin (2008, p. 64) como sendo "aquele praticado por colegas de serviço através de brincadeiras maldosas, piadas, palavras de grosseria, gestos obscenos, isolamento da vítima dos outros colegas de serviços”.

As pessoas que são assediadoras podem ter estes comportamentos devido a conflitos pessoais internos que acarretam dificuldades de se relacionar com as outras pessoas pelas suas características pessoais, profissionais, por disputas de cargos e até mesmo por discriminação sexual. (ALKIMIN,2008). 
O assediante, como autor do assédio moral prejudica diretamente a honra e a dignidade da pessoa assediada, podendo responder por perdas e danos e ainda, ser demitido pelo empregador por justa causa (CLT, art. 482, “b”, “j”) 4 . Mesmo o empregador demitindo o assediante não exclui a responsabilidade pelo dano moral sofrido pela vítima.

\subsubsection{Assédio moral vertical ascendente}

O assédio moral ascendente, no entendimento de Alkimin (2008, p.65) é aquele em que agressão "parte de um ou vários subordinados contra o superior hierárquico".

Guedes (2008, p. 53) ensina que: "uma das razões para a ocorrência do assédio vertical ascendente costuma ser a promoção de um colega sem aquiescência da equipe com quem vai trabalhar ou porque os colegas não reconhecem os méritos do promovido".

Nesse sentido, pode ocorrer o assédio moral ascendente contra o superior quando a equipe de trabalho não aceita ou não reconhece a sua capacidade, ressalta-se que para configurar esse tipo de assédio a conduta deve ser praticada pelo empregado contra o seu superior hierárquico.

Alkimin (2008) entende que quando o superior ultrapassa o seu poder de mando, agindo de forma arrogante e autoritária contra seu funcionário, abusando de seu poder, pode ser motivo para o empregado procurar formas de eliminar o superior praticando assim o assédio moral ascendente.

\subsubsection{Assédio Moral Vertical Descendente}

O assédio moral descendente é aquele que é praticado pelo empregador ou por outro superior hierárquico (como diretor, chefe, assessor, supervisor dentre outros) contra o empregado subalterno, fazendo ele passar por diversas situações constrangedoras, vexatórias e desumanas. (ALKIMIN, 2008)

Nesse diapasão, Hirigoyen (2010, p. 112) aduz que o assédio descendente é:

O assédio perverso, praticado com o objetivo puramente gratuito de eliminação do outro ou valorização do próprio poder; o assédio estratégico, que se destina a forçar o empregado a pedir as contas e assim contornar os procedimentos legais de dispensa; e o assédio institucional, que é um instrumento de gestão do conjunto pessoal.

O Assédio Descendente pode ter dois motivos: pode ser praticado por abuso de

\footnotetext{
${ }^{4}$ https://www.jusbrasil.com.br/topicos/10766433/decreto-lei-n-5452-de-01-de-maio-de-1943
} 
poder, no qual o superior hierárquico usando do poder que o cargo lhe confere pratica ato lesivo a honra e boa fama do empregado; ou o pratica como estratégia para que o empregado peça demissão (ÁVILA, 2008) ${ }^{5}$.

Entende-se que esse tipo de assédio é o que mais acontece no ambiente de trabalho tendo em vista a crescente competitividade e lucro a baixo custo, o que exige mais dos trabalhadores para alcançar as metas impostas, com grande exigência do superior, com ameaças de perder o emprego diante da grande dificuldade de conseguir se inserir novamente no mercado de trabalho.

\title{
2.2.4 Assédio moral misto
}

O assédio moral misto é o tipo de conduta que ocorre muito raramente pois ela se configura quando a vítima é assediada pelos colegas e também pelo seu superior. Costuma-se acontecer em locais de trabalhos com grande competividade interna cominado com mal gerenciamento dentro da empresa, como também em locais onde há grandes exigências (GUEDES, 2008).

\section{CONSEQUÊNCIAS DO ASSÉDIO MORAL NO TRABALHO PARA A VÍTIMA.}

A vítima que sofre por assédio moral no trabalho pode ter sua saúde física e psicológica atingida, podendo ocasionar danos irreparáveis.

No entendimento de ALKIMIN (2008, p. 83) pode-se compreender que:

\begin{abstract}
O assédio moral gera sofrimento psíquico que se traduz em mal-estar no ambiente de trabalho e humilhação perante os colegas de trabalho, manifestando o assediado sentimento e emoção por ser ofendido, menosprezado, rebaixado, excluído, vexado, cujos sentimentos se apresentam como medo, angústia, mágoa, revolta, tristeza, vergonha, raiva, indignação, inutilidade, desvalorização pessoal e profissional, que conduzem a um quadro de depressão com total perda da identidade e dos próprios valores, com risco de suicídio.
\end{abstract}

Diante deste entendimento é notável como o assédio moral pode atingir a vítima de forma severa, percebe-se que o assediado sofre um forte abalo psíquico, causando-lhe sentimentos de inferioridade, atingindo sua personalidade, podendo ter como resultado a depressão e em casos mais graves até o suicídio.

Nesse passo, a vítima pode sofrer traumas físicos e psicológicos que são resultados

\footnotetext{
${ }^{5}$ http://www.dominiopublico.gov.br/download/teste/arqs/cp067933.pdf
} 
do assédio moral:

\begin{abstract}
Danos à integridade psíquica e física como um todo, sentimento de inutilidade, transtorno de estresse pós-traumático, cefaleias agudas, dores generalizadas, sensação de mal-estar, palpitações, taquicardias, sensação de pressão no peito, falta de ar, tremores, crises de choro, fadiga crônica, insônia ou sonolência excessiva, depressão, apatia, angústia, melancolia, raiva, ansiedade generalizada, transtorno de personalidade, sensação de opressão, inquietação, desconfiança sem fundamento real, nervosismo, dores abdominais, diminuição da libido, sede de vingança, irritabilidade, impaciência, aumento de pressão arterial, problemas hormonais, problemas de memória, confusão mental, pesadelos relacionados ao trabalho, distúrbios digestivos, problemas de pele com alergias, problemas musculoesqueléticos, coceiras, tiques nervosos, agorafobia, consumo de drogas, consumo de álcool, hipertensão arterial, medo, descontrole emocional, mania de perseguição, sentimento de culpa, fobias, isolamento social, problemas nas relações familiares, dificuldade de interagir em equipe, competição exagerada, tristeza, síndrome de burnout, síndrome do pânico, absteísmo, baixa autoestima, atitudes agressivas, falta de ar, suores, ideação suicida, tentativa de suicídio. (CANDIDO 2011, p. 73)
\end{abstract}

Assim é possível analisar que a vítima atingida, pode sofrer de diversas doenças físicas e psicológicas, os sintomas podem variar de pessoa para pessoa.

Percebe-se que é de suma importância que o assediado procure ajuda médica e jurídica, para que receba o tratamento correto e conheça seus direitos.

\title{
4. ELEMENTOS CARACTERIZADORES DO ASSÉDIO MORAL
}

Para que seja configurado o assédio moral é fundamental alguns requisitos essenciais que serão abordados no presente artigo.

A Conduta abusiva é um dos requisitos configuradores do assédio moral e se perfaz quando as atitudes do assediador ultrapassam o que é permitido a um superior, buscando atingir pessoalmente a vítima, entendimento este defendido por Silva (2004, p.102) onde destaca que é de suma importância que a ação seja dolosa "ilícita e que tenha a finalidade de discriminar, marginalizar, ou de qualquer outro meio, prejudicar o trabalhador".

Segundo Silva (2004, p. 102) “deverá a perseguição ser quase que diária”, é necessário também que a conduta seja repetida e prolongada, atingindo a vítima psicologicamente. Diante desse entendimento é possível analisar que essa ação ilícita pode causar na vítima sentimentos de inferioridade e humilhação, refletindo no seu dia a dia de forma a transformar seu ambiente de trabalho em um local insuportável de se trabalhar.

Além disso a vítima do assédio moral tem sua dignidade psíquico-emocional abalada 
com atitudes desumanas que ferem a sua personalidade. Segundo Pamploma (2006, p.7)

o dano psíquico-emocional deve ser entendido como a consequência natural da violação aos direitos da personalidade da vítima" afirmando ainda que "esse elemento nem sempre estará presente no assédio moral, mas que as agressões sofridas poderão atingir sua dignidade moral e ser objeto de responsabilidade civil. ${ }^{6}$

Conforme Nascimento (2004) outro elemento caracterizador do assédio moral é a finalidade do agente de destruir e excluir a vítima, procurando meios para que ela peça demissão do serviço, e cometa erros que resultem na despedida pelo empregador, ou até mesmo que transforme o local de trabalho em ambiente degradante, objetivando que a vítima peça demissão, se aposente ou se licencie por motivos de saúde.

\section{O ASSÉDIO MORAL E A RESPONSABILIDADE CIVIL}

O Código Civil $^{7}$ de 2002 traduz a definição legal da responsabilidade civil que compreende na obrigação de recompensar a vítima que sofreu o dano, tendo como resultado sancionatório a indenização, seja por dano material ou moral.

$\mathrm{O}$ ato que causa dano ocasiona o dever de indenizar. $\mathrm{O}$ modo de reparar o dano causado a outrem tem como base o princípio da reparação do prejuízo causado, cuja finalidade é cuidar da segurança jurídica e a sanção civil pelo ato ilícito praticado ao lesado.

O dano patrimonial é de fácil compreensão porque atinge os bens materiais, como uma casa, um carro etc. Já o dano extrapatrimonial atinge a esfera subjetiva do sujeito, passível de ser valorado, pois fere direitos básicos da personalidade, como as emoções e o estado psicológico. aduzindo que:

O artigo 186 e 187 do $\mathrm{CC} / 2002^{8}$ trazem expressamente o conceito de ato ilícito

Art. 186. Aquele que, por ação ou omissão voluntária, negligência ou imprudência, violar direito e causar dano a outrem, ainda que exclusivamente moral, comete ato ilícito.

Art. 187. Também comete ato ilícito o titular de um direito que, ao exercê-lo, excede manifestamente os limites impostos pelo seu fim econômico ou social, pela boa-fé ou pelos costumes.

O conceito de responsabilidade civil pode ser encontrado no artigo 927 do Código

\footnotetext{
${ }^{6}$ https://jus.com.br/artigos/8838

${ }^{7}$ https://www2.senado.leg.br/bdsf/bitstream/handle/id/70327/C\%C3\%B3digo\%20Civil\%202\%20ed.pdf

${ }^{8}$ https://www2.senado.leg.br/bdsf/bitstream/handle/id/70327/C\%C3\%B3digo\%20Civil\%202\%20ed.pdf
} 
Civil9:

Art. 927. Aquele que, por ato ilícito causar dano a outrem, fica obrigado a repará-lo. Parágrafo único. Haverá obrigação de reparar o dano, independentemente de culpa, nos casos especificados em lei, ou quando a atividade normalmente desenvolvida pelo autor do dano implicar, por sua natureza, risco para os direitos de outrem.

Dispõe o art. 932, inc. III, do CC/2002 ${ }^{10}$ que: "São também responsáveis pela reparação civil: [...] o empregador ou comitente, por seus empregados, serviçais e prepostos, no exercício do trabalho que lhes competir, ou em razão dele".

O CC/02 cuidou de estabelecer alguns parâmetros sancionatórios para aquele que comete ato ilícito, ficando obrigado a repará-lo, inclusive nas relações de trabalho, o empregador pode ser responsável pela reparação se o ato ilícito foi praticado no exercício do trabalho ou em razão dele.

Muito se questiona a questão dos meios de provas quando se trata de assédio moral, levando em consideração que a violência sofrida pela vítima fere sua personalidade e seus sentimentos, dificultando assim valorar a quantidade da dor que foi sofrida, pois não há possibilidade de corrigir a dor, ou de saber se o sentimento deve ser objeto de reparação.

Alkimin (2008, p.113) aduz que:

Para a reparação do dano moral, é imprescindível a prova dos fatos que dão causa ao dano moral, entretanto, é prescindível a prova da dor, sofrimento e perturbação interior causada pela conduta ilícita, pois a doutrina e jurisprudência admitem a teoria do danun in re ipsa, para a qual o dano se prova por si mesmo, ou seja, provando o ilícito, dispensa-se a prova do prejuízo moral in concreto, pois ferir os direitos de personalidade e afetar o mais íntimo sentimento humano, é de difícil constatação.

Para os casos em que o assédio moral causar dano patrimonial, não há muita dificuldade em valorar a reparação pecuniária, pois é possível mensurar o tamanho do prejuízo causado pelo dano. Diante disso, a reparação procura restabelecer os danos emergentes, lucros cessantes, que vier sobre o patrimônio que foi lesado.

O assediador pode ser responsabilizado civilmente por suas ações praticadas, essa responsabilização objetiva punir o assediador e de alguma forma consolar a vítima.

No dia 13 de julho de 2017 foi sancionada a lei $\mathrm{N}^{\mathrm{o}}$ 13.467/2017 ${ }^{11}$ denominada como Reforma Trabalhista que começou a vigorar no dia onze de novembro do mesmo ano, colocando parâmetros para fixação de indenização que será paga para a vítima na relação de

\footnotetext{
9 idem

10 ibidem

${ }^{11}$ http://www.planalto.gov.br/ccivil_03/_ato2015-2018/2017/lei/113467.htm
} 
trabalho.

As alterações dessa lei modificaram artigos do Decreto-lei $n^{\circ} 5.452^{12}$, conhecida como Consolidação das leis do Trabalho estabelecendo o valor da reparação do dano de acordo com a gravidade da violência e tendo como base de cálculo o salário do ofendido.

\subsection{Elementos caracterizadores da responsabilidade civil}

A reponsabilidade civil possui elementos essenciais para sua configuração. Segundo Venosa (2013, p.5) são quatro os elementos caracterizadores da obrigação de indenizar, sendo eles “a ação ou omissão voluntária, dano, relação de causalidade e a culpa.

Por outro lado, Diniz (2011, p. 53, 54) defende que são apenas três elementos que caracterizam a responsabilidade civil sendo eles a "ação ou omissão, dano e a relação de causalidade".

É possível também extrair do Código Civil, no seu artigo 186 esses elementos, como pode-se verificar: "Aquele que, por ação ou omissão voluntária, negligência ou imprudência, violar direito e causar dano a outrem, ainda que exclusivamente moral, comete ato ilícito"13.

Diante do exposto analisar-se-á brevemente cada requisito da responsabilidade civil.

\subsubsection{Dano causado}

É de fundamental importância a existência do dano para a vítima.

Nota-se que o dano previsto no artigo 186 do Código Civil ${ }^{14}$, é aquele que a ação do agressor prejudica a vítima, desrespeitando a legislação. Melo (2005) classifica o dano sofrido como sendo a agressão e violação ao direito do ser humano, podendo ser material ou imaterial. Defende ainda que o primeiro gera à vítima a destruição ou redução de algum bem ou valor econômico e o segundo é aquele que atinge a personalidade da pessoa humana. (MELO, 2005)

No entendimento de Diniz (2011, p. 80) “o dano pode ser definido como a lesão (diminuição ou destruição) que, devido a um certo evento, sofre uma pessoa, contra sua vontade, em qualquer bem ou interesse jurídico, patrimonial ou moral”.

É notável que o assédio moral produz danos a pessoa assediada, tendo como

\footnotetext{
${ }^{12}$ https://www.jusbrasil.com.br/topicos/10766433/decreto-lei-n-5452-de-01-de-maio-de-1943

${ }^{13}$ https://www2.senado.leg.br/bdsf/bitstream/handle/id/70327/C\%C3\%B3digo\%20Civil\%202\%20ed.pdf

${ }^{14} \mathrm{http}: / /$ www.jusbrasil.com.br/topicos/10766433/decreto-lei-n-5452-de-01-de-maio-de-1943.
} 
premissa o fato do sofrimento psicológico, atingindo sua personalidade, e resultando em danos físicos que refletem na sua saúde.

\subsubsection{Ação ou omissão voluntária}

A conduta do assediador pode trazer como consequência a responsabilidade civil, através da ação ou omissão, que resulte em violência a vítima do assédio moral no trabalho, configurando-se ato ilícito para o ordenamento jurídico.

Para a caracterização da ilicitude é necessário que exista a conduta humana, de forma voluntária, como bem expressa:

\footnotetext{
A ação, elemento constitutivo da responsabilidade, vem a ser o ato humano, comissivo ou omissivo, ilícito ou licito, voluntario e objetivamente imputável do próprio agente ou de terceiro, ou o fato de animal ou coisa inanimada, que cause dano a outrem, gerando o dever de satisfazer os direitos do lesado. (DINIZ, 2011, p.56):
}

Percebe-se que é de suma importância que a conduta seja de forma voluntária, considerada ilícita na legislação, e que o agente tenha a liberdade de escolher o que fazer. Destacando-se que a ação quando não for voluntária não será então considerada como elemento da responsabilidade civil.

Diante do exposto, compreende-se que o agente quando voluntariamente pratica atos de assédio moral contra a vítima, causando danos psicológicos, físicos e atingindo a dignidade da pessoa humana, deve responder por sua conduta ilícita.

\subsubsection{Culpa do agente}

A culpa em sentido amplo configura-se como requisito para caracterizar a responsabilidade civil subjetiva quando há violação do dever legal ou contratual.

Segundo Venosa (2013) entende-se que a culpa ocorre quando há intenção na conduta ou ato que o agente deveria observar e não se atentou causando o ilícito, praticando-se então condutas de negligência, imprudência ou imperícia. Pode a culpa ser dividida em levíssima, leve ou grave, o que trará as consequências cabíveis para cada uma delas.

Nas palavras de Stoco (2007, p. 133) cita-se: 
surgir, por imprudência ou negligencia, existe a culpa (stricto sensu).

Negligência no entendimento de Souza $(2014)^{15}$ é resultado da falta de cuidado diante de algumas situações, quando esperado que seja realizado a ação, isso no assédio moral pode-se ocorrer quando o superior hierárquico está diante de situação que precisa agir para impedir a violência, mas permanece inerte.

Souza $(2014)^{16}$ entende também que outro requisito da culpa é a imperícia, sendo o resultado da falta de qualificação técnica para exercer alguma profissão ou a ausência de conhecimento do ato, o agente causador do dano a outra pessoa por falta destes requisitos deverá ser responsabilizado civilmente.

E por fim tem-se também como forma de culpa aquela em que o agente age de forma ilícita com imprudência. Segundo Souza $(2014)^{17}$, quando o assediador por impulso e sem o devido cuidado causa dano a outra pessoa, isso pode acontecer no ambiente de trabalho quando há ocorrência de assédio moral, essa ação pode ser em algumas situações de má-fé.

Já o dolo é caracterizado quando o agente pratica a conduta com intenção de prejudicar alguém, manifestando a vontade de obter resultado criminoso ou de produzir o risco.

Segundo Silva (2004) o assédio moral configura-se quando a pessoa assediadora comete com a intenção de praticar o dolo e com o objetivo exclusivamente de desonrar o trabalhador de forma abusiva principalmente na sua vida pessoal.

\subsection{5- Nexo de causalidade}

Outro requisito fundamental da responsabilidade civil é o nexo causal que há entre fato ilícito e o dano causado. Nesse sentido Venosa (2013, p. 54) aduz:

\footnotetext{
É por meio do exame da relação causal que se concluí quem foi o causador do dano. Trata-se de elemento indispensável. A responsabilidade objetiva dispensa a culpa, mas nunca dispensará o nexo causal. Se a vítima, que experimentou um dano, não identificar o nexo causal que leva o ato danoso ao responsável, não há como ser ressarcida.
}

Noronha (2010, p. 499) defende que "o nexo de causalidade é o elo entre o dano e o fato gerador, é o elemento que indica quais são os danos que podem ser considerados como

\footnotetext{
${ }^{15} \mathrm{http}: / /$ jus.com.br/artigos/37317/atos-ilicitos-responsabilidade-civil

16 idem

17 ibidem
} 
consequência do fato verificado."

Segundo o entendimento de Diniz (2011 p. 127) “o vínculo entre o prejuízo e a ação designa-se nexo causal de modo que o fato lesivo deverá ser oriundo da ação diretamente ou com sua consequência previsível".

Diante dos entendimentos acima citados pode-se analisar que é de suma importância que seja provado o nexo de causalidade para se configurar a responsabilidade civil.

\section{DA DIGNIDADE DA PESSOA HUMANA}

A Constituição Federal defende em seus artigos a proteção à dignidade da pessoa humana, priorizando o respeito à sua dignidade, vedando qualquer situação que viole direitos fundamentais, o que pode ser verificado na Constituição Federal no seu artigo $1^{\circ}$ e incisos III e IV que diz:

Art. $1^{\circ}$-A República Federativa do Brasil, formada pela união indissolúvel dos Estados e Municípios e do Distrito Federal, constitui-se em Estado Democrático de Direito e tem como fundamentos: [...] III - a dignidade da pessoa humana; IV - Os valores sociais do trabalho e da livre iniciativa. ${ }^{18}$

A condição de ser humano é requisito necessário para a proteção à dignidade humana como pode ser analisado no artigo citado na Constituição Federal.

Silva (1967, apud Silva, 2018, p.2) aduz sobre a dignidade:

[...] dignidade é a palavra derivada do latim dignitas (virtude, honra, consideração), em regra se entende a qualidade moral, que, possuída por uma pessoa serve de base ao próprio respeito em que é tida: compreende-se também como o próprio procedimento da pessoa pelo qual se faz merecedor do conceito público; em sentido jurídico, também se estende como a dignidade a distinção ou a honraria conferida a uma pessoa, consistente em cargo ou título de alta graduação; no Direito Canônico, indica-se o benefício ou prerrogativa de um cargo eclesiástico. ${ }^{19}$

Entende-se que a prática do assédio moral viola o princípio da dignidade humana, diante da premissa de que há o desrespeito e a violência no ambiente de trabalho causando sérios riscos à saúde física e psicológica, afetando diretamente a dignidade humana conforme está expresso na Constituição Federal e na doutrina.

Além disso, a Constituição Federal de 1988 defende o bem-estar nas relações de trabalho, o que pode ser destacado nos artigos 170 e 193 da Constituição ${ }^{20}$ onde explicita:

\footnotetext{
${ }^{18}$ http://www.planalto.gov.br/ccivil_03/constituicao/constituicao.htm

${ }^{19}$ https://jus.com.br/artigos/63882

${ }^{20}$ http://www.planalto.gov.br/ccivil_03/constituicao/constituicao.htm
} 


\begin{abstract}
Art. 170. A ordem econômica, fundada na valorização do trabalho humano e na livre iniciativa, tem por fim assegurar a todos existência digna [...];

Art. 193. A ordem social tem como base o primado do trabalho, e como objetivo o bem-estar e a justiça sociais.
\end{abstract}

Percebe-se que há a preocupação do legislador em defender a valorização do trabalho e a dignidade da pessoa humana como requisitos indispensáveis para o bem-estar e a justiça social, deve-se observar que o assédio moral no trabalho viola esses princípios e também outros previstos na lei.

$\mathrm{Na}$ visão da Constituição fica nítido que condutas como estas de assédio são consideradas abusivas ferindo o bem-estar no trabalho e a justiça social. A vitimóloga francesa Marie-France Hirigoyen (2010) cita que essas condutas são demonstradas através de atos, gestos, humilhações, xingamentos, manifestações escritas ou por palavras, que possam danificar a dignidade ou integridade psicológica ou mesmo física de uma pessoa, colocando em risco seu emprego e transformando seu ambiente de trabalho degradante.

A Constituição Federal é clara ao defender os direitos dos trabalhadores, desta maneira pode-se concluir que tanto o agressor como a empresa que permitir que seja praticado o assédio moral, serão responsabilizados pelas suas condutas de ação ou omissão, visto que estão violando os princípios constitucionais.

\title{
7. ASSÉDIO MORAL E A LEGISLAÇÃO TRABALHISTA
}

A Consolidação das Leis do Trabalho elenca as ações que tipificam faltas consideradas graves quando cometidas pelo empregador contra seu funcionário conforme artigo 483 da CLT:

O empregado poderá considerar rescindido o contrato e pleitear a devida indenização quando: a) forem exigidos serviços superiores às suas forças, defesos por lei, contrários aos bons costumes, ou alheios ao contrato; b) for tratado pelo empregador ou por seus superiores hierárquicos com rigor excessivo; c) correr perigo manifesto de mal considerável; d) não cumprir o empregador as obrigações do contrato; e) praticar o empregador ou seus prepostos, contra ele ou pessoas de sua família, ato lesivo da honra e boa fama; f ) o empregador ou seus prepostos ofenderem-no fisicamente, salvo em caso de legítima defesa, própria ou de outrem; g) o empregador reduzir o seu trabalho, sendo este peça ou tarefa, de forma a afetar sensivelmente a importância dos salários. ${ }^{21}$

O empregador ao exigir de seu funcionário que exerça funções além de suas forças, ou quando o faz passar por humilhações, ofensas, danos físicos e psicológicos entre outros

\footnotetext{
${ }^{21}$ https://www.jusbrasil.com.br/topicos/10766433/decreto-lei-n-5452-de-01-de-maio-de-1943
} 
oriundos do assédio moral no trabalho, viola a legislação trabalhista.

$\mathrm{Na}$ ocorrência dessas condutas ilícitas o empregado pode usar de seu direito de pedir a rescisão indireta do contrato de trabalho. No citado artigo, pode-se analisar que o assédio moral no ambiente de trabalho, atinge diretamente o trabalhador, ensejando a violação aos direitos já elencados nesse artigo devendo ser pleiteado as indenizações devidas.

Quando na ocorrência de assédio em que o superior hierárquico tem a obrigação de agir, mas tende a omissão tem-se a possibilidade segundo a jurisprudência de se enquadrar no artigo 483, da CLT.

A jurisprudência nesse sentido diz que:

ASSÉDIO MORAL. CONFIGURAÇÃO. O assédio moral consiste em atos e comportamentos praticados por empregador, superior hierárquico ou colegas de trabalho, que se traduzem em atitude de contínua e ostensiva perseguição que acarretem danos relevantes às condições físicas, psíquicas e morais da vítima. Uma vez comprovada a sua ocorrência, há que se falar em direito ao pagamento de indenização. (TRT-5 - RecOrd: 00001416320145050131 BA, Relator: LÉA NUNES, $3^{\text {a }}$. TURMA, Data de Publicação: DJ 28/02/2019) ${ }^{22}$

Já quando o assédio moral for contra o superior hierárquico ou contra os próprios colegas de serviços, sem relação de hierarquia, tem-se a possibilidade, de ser punido com a justa causa prevista no artigo 482 alineas b, j e k da CLT, neste artigo encontra-se elencado que por ato de "incontinencia ou mau procedimento" e ainda praticar "atos lesivos contra a boa fama" e até mesmo intentar "contra a honra" praticando "ofensas físicas contra o empregador ou superiores hierárquico". ${ }^{23}$

Assim expressa o artigo 482 alineas b, j e k da CLT $^{24}$ sobre a justa causa:

Art. 482 - Constituem justa causa para rescisão do contrato de trabalho pelo empregador:

b) incontinência de conduta ou mau procedimento;

j) ato lesivo da honra ou da boa fama praticado no serviço contra qualquer pessoa, ou ofensas físicas, nas mesmas condições, salvo em caso de legítima defesa, própria ou de outrem;

k) ato lesivo da honra ou da boa fama ou ofensas físicas praticadas contra o empregador e superiores hierárquicos, salvo em caso de legítima defesa, própria ou de outrem; BRASIL. 2019.

Diante do artigo supracitado o empregador pode usar de seu poder hierárquico, de fiscalização e de disciplinar, quando na ocorrência do assédio advindo do empregado contra seu superior ou mesmo seu colega de serviço, infringindo a lei, ofendendo a dignidade humana, e na ocorrência de atos de ofensa a honra, violência física que ensejam a boa fama,

\footnotetext{
22 https://trt-5.jusbrasil.com.br/jurisprudencia/699365313/recurso-ordinario-record-1416320145050131-

ba/inteiro-teor-699365321?ref=juris-tabs

${ }^{23}$ https://www.jusbrasil.com.br/topicos/10766433/decreto-lei-n-5452-de-01-de-maio-de-1943.

${ }^{24}$ https://www.jusbrasil.com.br/topicos/10766433/decreto-lei-n-5452-de-01-de-maio-de-1943.
} 
aplicando a justa causa.

Nesse sentido pode-se citar exemplos de assédio moral contra superior hierárquico ou colega de serviço que resultam em justa causa:

Proferir palavras de baixo calão contra o superior ou colega, negar-se, reiteradamente, a cumprimentá-los ou ignorá-los, responder com sarcasmo ao superior hierárquico, ignorar suas ordens, chamar tanto o superior como o colega de "puxa-saco", "chato", "fresco", "burro", "besta", "idiota", apelidos humilhantes e degradantes etc.; difamá-los propagando assuntos pessoais ou familiares etc. ALKIMIN (2008, p.102)

Corroborando com o dever de reparar o dano, o art. 223-E incluído pela Lei $\mathrm{n}^{\circ}$ 13.467 de 13 de julho de 2017 assim dispõe: "São responsáveis pelo dano extrapatrimonial todos os que tenham colaborado para a ofensa ao bem jurídico tutelado, na proporção da ação ou omissão". 25

A CLT após alterações incluídas pela Lei 13467/2017 estabeleceu também os parâmetros para a fixação da reparação, conforme se pode vislumbrar da redação do art. 223G que assim dispõe:

\begin{abstract}
Art. 223-G. Ao apreciar o pedido, o juízo considerará: $\$ 1^{\circ}$ Se julgar procedente o pedido, o juízo fixará a indenização a ser paga, a cada um dos ofendidos, em um dos seguintes parâmetros, vedada a acumulação: I - Ofensa de natureza leve, até três vezes o último salário contratual do ofendido; II - Ofensa de natureza média, até cinco vezes o último salário contratual do ofendido; III - ofensa de natureza grave, até vinte vezes o último salário contratual do ofendido; IV - Ofensa de natureza gravíssima, até cinquenta vezes o último salário contratual do ofendido. $\S 2^{\circ} \mathrm{Se}$ o ofendido for pessoa jurídica, a indenização será fixada com observância dos mesmos parâmetros estabelecidos no $\S 10$ deste artigo, mas em relação ao salário contratual do ofensor. $\S 3^{\circ} \mathrm{Na}$ reincidência entre partes idênticas, o juízo poderá elevar ao dobro o valor da indenização. (BRASIL, 2019) ${ }^{26}$
\end{abstract}

Destaca-se que a legislação do trabalho com advento desta reforma cuidou de estabelecer de maneira taxativa os parâmetros usados para cada tipo de ofensa, atribuindo valor de acordo com a gravidade da ação, e tendo como base de cálculo o salário do ofendido.

Assim, ao praticar assédio moral no ambiente de trabalho, o agente causador pode ser responsabilizado pelos danos e também ter seu contrato rescindido por justa causa na empresa, sendo considerado falta grave tal atitude e inaceitável no ordenamento jurídico, a violação ao bem-estar no trabalho.

A jurisprudência do TST condenou o empregador a pagar indenização por assédio Moral:

\footnotetext{
${ }^{25}$ http://www.planalto.gov.br/ccivil_03/_ato2015-2018/2017/lei/113467

${ }^{26}$ https://www.jusbrasil.com.br/topicos/10766433/decreto-lei-n-5452-de-01-de-maio-de-1943.
} 


\begin{abstract}
AGRAVO EM AGRAVO DE INSTRUMENTO. INDENIZAÇÃO POR DANOS MORAIS. ASSÉDIO MORAL. VALOR ARBITRADO. O presente caso retrata situação de assédio moral, em que o empregador imprimia forte temor de demissão na empregada, com atitudes rudes, desconfiadas e intimidadoras. $\mathrm{O}$ e. TRT entendeu que o valor de $\mathrm{R} \$ 30.000,00$ (trinta mil reais) é razoável e proporcional, considerando os princípios da vedação do enriquecimento sem causa e da natureza didática e preventiva da sanção, e que estão atendidas as finalidades punitiva e indenizatória inerentes à condenação em relevo. O Tribunal Superior do Trabalho, na esteira do posicionamento do Superior Tribunal de Justiça, adotou o entendimento de que o valor das indenizações por danos morais só pode ser modificado nas hipóteses em que as instâncias ordinárias fixaram importâncias fora dos limites da proporcionalidade e da razoabilidade. Ou seja, quando a condenação se revelar teratológica, seja porque o valor é exorbitante, seja porque é irrisório, caso dos autos. Considerando os termos do artigo 944 do Código Civil, que dispõe que a indenização é mensurada pela extensão do dano e considerando o contexto delineado, insuscetível de revisão nesta instância superior, a decisão recorrida não merece reparos. Agravo conhecido e desprovido. (TST - Ag-AIRR: 15276520135070016, Relator: Alexandre de Souza Agra Belmonte, Data de Julgamento: 20/02/2019, $3^{\text {a }}$ Turma, Data de Publicação: DEJT 22/02/2019) ${ }^{27}$
\end{abstract}

O entendimento jurisprudencial do TRT3 também condenou por assédio moral o empregador por abuso do seu poder de exigência onde aduz que:

CUMPRIMENTO DE METAS. ABUSO NA EXIGÊNCIA. ASSÉDIO MORAL CONFIGURADO. INDENIZAÇÃO DEVIDA. A pressão para o cumprimento de metas é própria de determinados segmentos econômicos e se insere no poder diretivo conferido ao empregador, não configurando assédio moral desde que empreendida sem abusos, o que não ocorre quando o empregador, como na hipótese dos autos, passa a cobrar metas perante todos os empregados, classificando-os em rankings e fazendo referências negativas, havendo inclusive ameaça de dispensa em caso de baixo desempenho, visto que tal conduta constitui abuso de direito a teor do art. 187 do Código Civil e enseja reparação por danos morais. . (TRT da 3. ${ }^{a}$ Região; PJe: 0011266-27.2017.5.03.0180 (RO); Disponibilização: 30/11/2017; Órgão Julgador: Segunda Turma; Redator: Convocada Sabrina de Faria F.Leao). ${ }^{28}$

Conclui-se que é direito do ofendido de ser indenizado por todos os danos causados, sendo de fundamental importância que sejam punidos toda violação a dignidade humana, a saúde física, psicológica, a degradação do ambiente de no trabalho e qualquer conduta atentatória contra a vítima.

\title{
8. PROJETO DE LEI No 4.742/2001
}

Este projeto de lei que está em tramitação desde 2001, obteve no dia 12 de março de 2019 mais um avanço, onde foi votada e aprovada por unanimidade entre os deputados e encaminhada para o Senado Federal.

O projeto de lei versa sobre a tipificação do assédio moral, alterando o Código Penal

\footnotetext{
${ }^{27}$ https://tst.jusbrasil.com.br/jurisprudencia/679332136/agravo-de-instrumento-em-recurso-de-revista-ag-airr15276520135070016/inteiro-teor-679332156?ref=serp

${ }^{28} \mathrm{http}$ ://rafaelcmonteiro.blogspot.com/2018/08/jurisprudencia-do-trt-mg-sobre.html
} 
Decreto-Lei $n^{\circ} 2.848 / 40^{29}$ incluindo-o na sua redação.

O projeto de lei $\mathrm{n}^{\mathrm{o}} 4.742 / 2001^{30}$ acrescenta o artigo 146-A ao Código Penal, com a seguinte redação:

\begin{abstract}
Art. 146-A. Ofender reiteradamente a dignidade de alguém causando-lhe dano ou sofrimento físico ou mental, no exercício de emprego, cargo ou função. Pena detenção, de 1 (um) a 2 (dois) anos, e multa, além da pena correspondente à violência. $\S 1^{\circ}$ Somente se procede mediante representação, que será irretratável. $\S$ $2^{\circ}$ A pena é aumentada em até $1 / 3$ (um terço) se a vítima é menor de 18 (dezoito) anos. $\S 3^{\circ} \mathrm{Na}$ ocorrência de transação penal, esta deverá ter caráter pedagógico e conscientizador contra o assédio moral. ${ }^{31}$
\end{abstract}

Se aprovado o projeto o agressor sofrerá as penalidades previstas, pois ser-lhe-á atribuído o crime do assédio moral tipificado no código penal, onde pode-se inferir que esta é uma das formas de punição ao assediador, passando a responder também na esfera criminal, culminado em uma pena de detenção de 1 a 2 anos e multa, além de responder pela violência causada.

\title{
9. NECESSIDADE DE LEI FEDERAL QUE REGULAMENTE O ASSÉDIO MORAL NO AMBIENTE DE TRABALHO
}

No Brasil, ainda não foi criada uma lei federal para regulamentar o assédio moral.

A falta de uma lei específica de âmbito nacional que regulamente o Assédio Moral no ambiente de Trabalho é um fator que coloca em cheque os critérios a serem utilizados para a configuração do ilícito, bem como as penalidades que devem ser aplicadas. (AMARAL, $2017)^{32}$

Como pode-se analisar no presente artigo para julgar demandas sobre o assédio moral no ambiente de trabalho tem-se utilizado leis que não são específicas e jurisprudências, nota-se a urgência da criação dessa lei federal.

A regulamentação poderá sanar algumas dessas dúvidas, colocar limites claros e objetivos do que se configura o assédio moral no setor público e privado e quais as punições cabíveis. (AMARAL, 2017) ${ }^{33}$

No âmbito estadual existem algumas leis que regulamentam o assédio moral na administração Pública direta e indireta, vedando explicitamente a prática dessa conduta e

\footnotetext{
${ }^{29}$ http://www.planalto.gov.br/ccivil_03/decreto-lei/del2848compilado.htm

${ }^{30}$ https://www.camara.leg.br/proposicoesWeb/fichadetramitacao?idProposicao $=28692$

31 idem

${ }^{32}$ https://repositorio.ufu.br/bitstream/123456789/18599/6/AssedioMoralRelacoes.pdf

33 idem
} 
trazendo penalidades para o agente agressor.

No Estado de São Paulo tem-se a lei $\mathrm{n}^{\mathrm{o}} 12.250^{34}$, de 9 de fevereiro de 2006, esta lei traz em seu conteúdo o conceito de Assédio Moral na Administração Pública e buscou proteger a vítima de assédio trazendo vedações a prática, e no seu artigo $4^{\circ}$ fez previsão de penalidades como: "advertência, suspenção e demissão".

Além do Estado de São Paulo existem outros estados que buscaram regulamentar tal conduta. Em Goiás, a lei no 18.456 de 30 de agosto de $2014^{35}$, no Rio de Janeiro a lei $n^{\circ} 3921$, de 23 de agosto de 2002 ${ }^{36}$, e em Minas Gerais a Lei Complementar 116 ${ }^{37}$, de 11/01/2011, todas essas também procuraram formas de prevenir, vedar e penalizar a prática do assédio moral.

\section{CONSIDERAÇÕES FINAIS}

Ao pensar-se no ambiente de trabalho onde há relação entre patrão e empregado e até mesmo entre colegas de serviço espera-se que seja um ambiente que proporcione ao empregado e empregador um local digno e harmonioso de se trabalhar, respeitando as diferenças de cada pessoa e procurando sempre evitar situações que causem assédio.

Analisar o assédio moral no ambiente do trabalho não é bem simples como muitos podem pensar, tendo em vista que essa conduta na maioria dos casos acontece de forma silenciosa sem testemunhas e que até mesmo a vítima tem dificuldades de reconhecer, como foi possível detectar no presente artigo.

Ao deparar-se com assédio moral sofrido pelas vítimas pode-se perceber direitos sendo infringidos, e consequências físicas e psicológicas com grande impacto para o assediado.

Percebe-se que é possível responsabilizar civilmente o agente causador do assédio moral no trabalho, e de certa forma puni-lo pelo dano causado, buscando indenizar a vítima das agressões psicológicas e físicas sofridas, pelos danos emergentes, lucros cessantes, que vier sobre o patrimônio que foi lesado.

Em 2017, com a reforma trabalhista foram acrescentados alguns dispositivos na CLT que fazem previsão do dever de indenizar o ofendido e os valores da reparação.

\footnotetext{
${ }^{34}$ https://www.al.sp.gov.br/repositorio/legislacao/lei/2006/lei-12250-09.02.2006.html

${ }^{35} \mathrm{http}: / /$ www.gabinetecivil.go.gov.br/leis_ordinarias/2014/lei_18456.htm

${ }^{36} \mathrm{http} / / /$ alerjln1.alerj.rj.gov.br/contlei.nsf/f25edae7e64db53b032564fe005262ef/3dcfce02b06be53903256c28005 37184? OpenDocument\&Highlight=0,3921

${ }^{37} \mathrm{https}: / /$ www.almg.gov.br/consulte/legislacao/completa/completa.html?num=116\&ano=2011\&tipo=LCP
} 
Mesmo com a referida previsão legal, percebe-se a necessidade de haver uma lei no âmbito federal que regulamente as situações de assédio moral, bem como critérios para a fixação da reparação. A pesquisa demonstrou que alguns estados cuidaram de regulamentar o assédio moral, porém a maioria deles com enfoque no assédio moral no âmbito da Administração Pública direta e indireta, não fazendo previsão do fato nas demais relações de trabalho.

Compreende-se que é muito importante o estudo feito no presente artigo tendo em vista que essa é uma realidade presente no ambiente de trabalho, podendo essa análise colaborar para o meio acadêmico de forma a conscientizar as pessoas sobre seus direitos e obrigações e prevenir o assédio moral no ambiente de trabalho.

\title{
MORAL ASSISTANCE IN THE WORK ENVIRONMENT AND THE CIVIL LIABILITY OF THE EMPLOYER
}

\begin{abstract}
This article deals with bullying in the workplace and the consequences for the harasser, such as options for legal, legislative and jurisprudential alternatives. Bullying harms, the worker's psychological, affecting in turn their well-being in the workplace. It can be seen from the present study that the routine of work has been subjected to humiliating situations and mistreatment in labor relations. However, judicial decisions can be taken to minimize the damages suffered by the aggressor. Thus, the research is made on the characteristic elements of bullying and a possibility of compensation for the offense practiced in the workplace. The propositions presented are not available through exploratory bibliographical research, analysis of jurisprudence, articles, legislation and doctrines. Counseling about moral assiduity in the workplace often presents itself by virtue of the vanguard or the pursuit of a professional who is ideal for the job market, making it necessary for the prevention of the working environment officials from the judicial and psychological consequences of an offensive conduct.
\end{abstract}

Keywords: Harassment; civil responsability; labor legislation.

\section{REFERENCIAS}

AGUIAR, André Luiz Souza. Assédio moral: o direito à indenização pelos maus-tratos e humilhações sofridos no ambiente de trabalho. $2^{\mathrm{a}}$ ed. São Paulo: LTr, 2006.

ALKIMIN, Maria Aparecida. Assédio moral na relação de trabalho. 2. ed. Curitiba: Juruá, 2008. 
AMARAL, Lucas Bernardes. Assédio moral nas relações de trabalho e seus desdobramentos. Universidade Federal De Uberlândia Faculdade De Direito "Professor Jacy De Assis. Uberlandia. 2017 Disponível em<https://repositorio.ufu.br/bitstream/123456789/18599/6/ AssedioMoralRelacoes.pdf $>$ Acesso em 10 de junho de 2019.

AVILA, Rosemari Pedrotti de. As consequências do assédio moral no ambiente de trabalho.2008. Disponível em:<http://www.dominiopublico.gov.br/download/teste/arqs/cp06

BRASIL. Constituição Federal de 1988. Promulgada em 5 de outubro de 1988. Disponível em: <http://www.planalto.gov.br/ccivil_03/constituicao/constituicao.htm>. Acesso em: 16 mai. 2019

BRASIL. Decreto Lei ${ }^{\circ}$ 5.452: Consolidação das Leis do Trabalho. Disponível em: https://www.jusbrasil.com.br/topicos/10766433/decreto-lei-n-5452-de-01-de-maio-de-1943. Acesso em: 22/05/2019

BRASIL. Decreto-lei No 2848, de 7 de dezembro de 1940.Código Penal. Disponível em: http://www.planalto.gov.br/ccivil_03/decreto-lei/del2848compilado.htm. Acesso em: $22 / 05 / 2019$

BRASIL. Lei n. 13.467, de 13 de julho de 2017.Altera a Consolidação das Leis do Trabalho. Diário Oficial da União, Brasília, DF, 17 de julho de 2017. Disponível em: http://www planalto.gov.br/ccivil_03/_ato2015-2018/2017/lei/113467.htm >. Acesso em: 29/05/2019.

BRASIL. TRIBUNAL REGIONAL DO TRABALHO DA $3^{\mathrm{a}}$ REGIÃO. RO: 001126627.2017.5.03.0180. Redator: Convocada Sabrina de Faria P. Leão, Segunda Turma. Data da publicação: 30/11/2017. Disponível em < http://rafaelcmonteiro.blogspot.com /2018/08/ jurisprudencia-do-trt-mg-sobre.html> Acesso em: 11 abr. 2019.

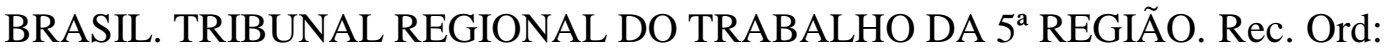
00001416320145050131 BA.Relator: LÉA NUNES, $3^{\text {a }}$. TURMA, , Data de Publicação: DEJT 22/02/2019. Disponível em < https://trt-5.jusbrasil.com.br/jurisprudencia/ 699365313 /recurso-ordinario-record-1416320145050131-ba/inteiro-teor-699365321?ref=juris-tabs > Acesso em: 12 abr. 2019.

BRASIL. TRIBUNAL SUPERIOR DO TRABALHO- Ag-AIRR: 15276520135070016, Relator: Alexandre de Souza Agra Belmonte, Data de Julgamento: 20/02/2019, $3^{\text {a }}$ Turma, Data de Publicação: DEJT 22/02/2019. Disponível em < https://tst.jusbrasil.com. br/jurisprudencia/679332136/agravo-de-instrumento-em-recurso-de-revista-ag-airr15276520135070016/inteiro-teor-679332156?ref=serp > Acesso em: 11 de maio de 2019)

BRASIL. Código civil: lei 10.406 de 10 de janeiro de 2002. Brasília: Senado Federal, Disponível em: https://www2.senado.leg.br/bdsf/bitstream/handle/id/70327/C\%C3\%B3 digo\%20Civil\%202\%20ed.pdf Acesso em: 29/05/2019.

CAMARA DOS DEPUTADOS. Projeto de lei $\mathbf{n}^{\mathbf{0}}$ 4.742/2001, assédio moral: Altera o Decreto-Lei $\mathrm{n}^{\circ}$ 2.848, de 7 de dezembro de 1940 (Código Penal), para tipificar o assédio moral Disponível em:<https://www.camara.leg.br/proposicoesWeb/fichadetramitacao ?idProposicao=28692>20 maio 2019 
CANDIDO, Tchilla Helena. Assédio moral: acidente laboral. São Paulo: LTr, 2011.

CAVALCANTE, Jouberto de Quadros Pessoa; JORGE NETO, Francisco Ferreira. O Direito do Trabalho e o assédio moral. Revista Jus Navigandi, ISSN 1518-4862, Teresina, ano 10, n. 638, 7 abr. 2005. Disponível em: 〈https://jus.com.br/artigos/6457〉. Acesso em: 10 jun. 2019

DARCANCHY, Mara Vidigal. Assédio moral no meio ambiente do trabalho. Revista Jus Navigandi, ISSN 1518-4862, Teresina, ano 11, n. 913,2 jan. 2006. Disponível em: <https:// jus.com.br/artigos/7765>. Acesso em: 20 maio 2019

DINIZ, Maria Helena. Curso de direito civil brasileiro, volume 7: responsabilidade civil. 25. Ed. São Paulo: Saraiva, 2011.

GOIÁS. Lei No 18.456 de 30 de agosto de 2014. Dispõe sobre a prevenção e a punição de assédio moral no âmbito da Administração estadual e dá outras providências. Disponível em < http://www.gabinetecivil.go.gov.br/leis_ordinarias/2014/lei_18456.htm>. Acesso em: 10 jun. 2019.

GUEDES, Márcia Novaes. Terror psicológico no trabalho. 3. Ed. São Paulo: LTr, 2008, p. 53.

HIRIGOYEN, M. F. Mal-Estar no Trabalho: redefinindo o assédio moral. 5. ed. Rio de Janeiro: Bertrand Brasil, 2010.

MARQUES JUNIOR, Fernando Antônio Apud CASTRO, Cláudio Roberto Carneiro de. O que você precisa saber sobre o assédio moral nas relações de emprego. 2. ed. São Paulo: LTr, 2014. p 22.

MELO, Nehemias Domingos de. Por Uma Nova Teoria da Reparação por Danos Morais. Revista do Instituto dos Advogados de São Paulo - IASP, v. 8, n. 15 (jan./jun.2005), p. 50.

MELO, Raul Henrique Beserra A evolução histórica do assédio moral nas relações de trabalho no Brasil e no mundo. Jus Navigandi. Maio de 2017.Disponível em: [https://jus.com.br/artigos/57476/a-evolucao-historica-do-assedio-moral-nas-relacoes-detrabalho-no-brasil-e-no-mundo ]Acesso em 19/05/2019

MINAS GERAIS. Lei Complementar 116/2011. Dispõe sobre a prevenção e a punição do assédio moral na administração pública estadual. Promulgada em, de 11 de janeiro de 2011. Disponível em<https://www.almg.gov.br/consulte/legislacao/completa/completa .html?num $=116 \&$ ano=2011\&tipo $=$ LCP $>$. Acesso em: 10 jun. 2019.

NASCIMENTO, Sonia A.C.M. O assédio moral no ambiente de trabalho. Revista LTr, São Paulo. 2004.

NORONHA, Fernando. Direito das obrigações. 3. ed. São Paulo: Saraiva, 2010. Pamplona Filho, Rodolfo. Assédio moral laboral e direitos fundamentais. São Paulo: LTr, 2014.

PAMPLONA FILHO, Rodolfo. Noções conceituais sobre o assédio moral na relação de emprego. Revista Jus Navigandi, ISSN 1518-4862, Teresina, ano 11, n. 1149, 24 ago. 2006. Disponível em: <https://jus.com.br/artigos/8838>. Acesso em: 12 jun. 2019. 
PEREIRA, Caio Mário da Silva. Responsabilidade Civil. 9. ed. Rio de Janeiro: Forense, 1999.

RIO DE JANEIRO. Lei $n^{\circ} 3921$, de 23 de agosto de 2002. Veda o assédio moral no trabalho no âmbito da administração publica direta e indireta. Disponível em <http:// alerjln1.alerj.rj.gov.br/contlei.nsf/f25edae7e64db53b032564fe005262ef/3dcfce02b06be53903 256c2800537184? OpenDocument\&Highlight=0,3921 >. Acesso em: 10 jun. 2019.

SÃO PAULO. Lei ${ }^{\circ} 12.250$, de 9 de fevereiro de 2006 . Veda o assédio moral no âmbito da administração pública estadual direta, indireta e fundações públicas. Disponível em< https://www.al.sp.gov.br/repositorio/legislacao/lei/2006/lei-12250-09.02.2006.html >. Acesso em: 10 jun. 2019.

SILVA, Edvaldo do Carmo Silva. Responsabilização civil do assédio moral no trabalho. Revista Jus Navigandi, ISSN 1518-4862, Teresina, ano 23, n. 5622, 22 nov. 2018. Disponível em: <https://jus.com.br/artigos/63882>. Acesso em: 10 jun. 2019.

SILVA, Luiz de Pinho Pedreira da. A reparação do dano moral no direito do trabalho. São Paulo: LTR, 2004.

SOUZA, Augusto Rosa. Atos Ilícitos: responsabilidade Civil (2014). http://jus.com.br/artigos/37317/atos-ilicitos-responsabilidade-civil. Acesso em 10/06/2019.

STOCO, Rui. Tratado de responsabilidade civil: doutrina e jurisprudência. 7 ed. São Paulo Editora Revista dos Tribunais, 2007.

VENOSA, Sílvio de Salvo. Direito civil: responsabilidade civil. 13. ed. v.4. São Paulo: Atlas, 2013. 